\title{
Measurement of Spatial Variation of Rainfall in Cuddalore District using Ilwis
}

\author{
S.Sivaprakasam, K.Karthikeyan, N.Nagarajan, Visalachi
}

\begin{abstract}
Rainfall is a one of the important phenomena of the hydrological cycle; its distribution time to time, varies from one place to another place; and it acts as a source of water to the earth. Indian agriculture and the cropping pattern, with good yield of production, depend on the rainfall during monsoon. According to the IMD, South peninsular region got $40 \%$ of rainfall from South-West monsoon and 60\% from North-East monsoon. This study aims at understanding the spatial distribution of rainfall and its influences in the hydrological trend of precipitation over the area which is closely linked with flood and drought. For the purpose of evaluation, the rainfall data of 21 stations were collected from statistical department and PWD Ground water division of Cuddalore district during period of 1986 - 2016. After error correction and checking, the general methodology was applied for this study. The collected data and the real time data were matched for the mathematical analysis to find the Mean, Seasonal variation, Coefficient of Variation, Precipitation Ratio. The spatial distribution of rainfall convert as the non spatial data of an attribuutive information in the form of statistics, tabled list, graphs and finally, using the ILWIS software, to find the influence of rainfall over the area were identified and demarcated with maps. The long term rainfall analysis identifies the influence and pattern of spatial distribution of Cuddalore district.
\end{abstract}

Key words:-Rainfall, Monsoon, Spatial distribution, Hydrological trend.

\section{INTRODUCTION}

Universally, water is the main commodity playing major role in world economy. The main source of fresh water is rainfall. According to NASA, the most obvious pattern, in the total rainfall maps, is the change in seasons. A band of heavy rain moves North and South of the Equator seasonally. About two-thirds of all rain falls along or near the equator. Rainfall is an important phenomena in the hydrological cycle. It plays a major role in planning of water resource projects, agriculture and other related domains. Tamilnadu is a tropical State in India. Its climate varies from dry sub humid to semi arid. The pattern of rainfall is not a constant as it varies from time to time and place to place. The variability of rainfall alters the cropping pattern. Rainfall is an agro-climatological factor that prevails in the seasonally arid parts of the world and its analysis is an important prerequisite for agricultural planning in India

Revised Manuscript Received on April 12, 2019.

S.Sivaprakasam,Assistant Professor, Department of Civil Engineering, Faculty of Engineering and Technology, Annamalai University, Annamalai Nagar, Tamilnadu, India. (sivacdm67@gmail.com)

K.Karthikeyan,Assistant Professor, Department of Civil Engineering, Faculty of Engineering and Technology, Annamalai University, Annamalai Nagar, Tamilnadu, India.

N.Nagarajan,Assistant Professor, Department of Civil Engineering, Faculty of Engineering and Technology, Annamalai University, Annamalai Nagar, Tamilnadu, India.

Visalachi, PG student, Department of Civil Engineering, Faculty of Engineering and Technology, Annamalai University, Annamalai Nagar, Tamilnadu, India.
(AlakGadgil - 1986). Hydrologists require timescale, detailed knowledge of the frequency, volume and spatial distribution of the precipitation to assess the local imparts of impending extreme weather events to adapt to climate change (Fowler et.al. 2007). The annual and seasonal rainfall along with its variability has been analyzed for Cuddalore District, Tamilnadu, busing the QGIS software (Sandeep, et. al 2018). The current study focuses attention on the spatial distribution of the rainfall, coefficient of variability and precipitation ratio.

\section{STUDY AREA}

Cuddalore district is located at the geographical coordinates of $11^{\circ} 11^{\prime \prime}$ to $12^{\circ} 35^{\prime \prime} \mathrm{N}$ latitude, $78^{\circ} 38^{\prime \prime}$ to $80^{\circ}$ $0 " \mathrm{E}$ longitude and altitude is $4.6 \mathrm{~m} \mathrm{MSL}$. The study area is the Eastern part of Tamilnadu and is surrounded by Villupuram, Nagapattinam and Perambalur on North, South and West respectively and on East by Bay of Bengal as shown in figure 1 . The total area is about $36.78 \mathrm{sq} . \mathrm{km}$. The average temperature ranges from $24.4^{\circ} \mathrm{C}$ during January to maximum of $32{ }^{\circ} \mathrm{C}$ during June. The coastal region of the study area like Parangipettai, Chidambaram, Bhuvanagiri have an altitude of 5-6 m above the MSL. The central regions of the study area have an altitude of 9-10 $\mathrm{m}$ above MSL. The minimum altitude is observed in the South and it is found ascending as it moves towards the north. The western regions of the study area have an altitude of about $45 \mathrm{~m}$ above the MSL.

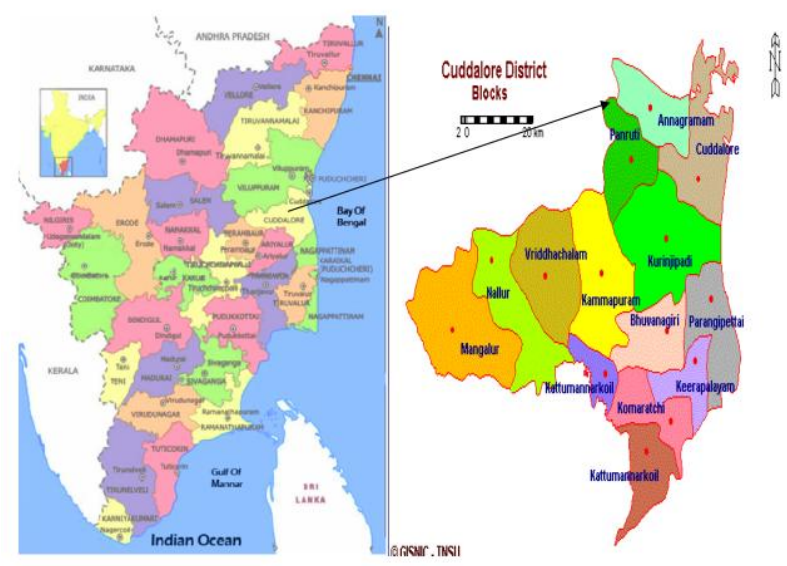

Figure1 Map of Cuddalore district

Published By: 


\section{OBJECTIVES}

- To determine the Coefficient of variation and Precipitation Ratio.

- To plot the Spatial distribution map with the help of ILWIS.

- To locate and demarcate the abnormality of rainfall area.

\section{METHODOLGY}

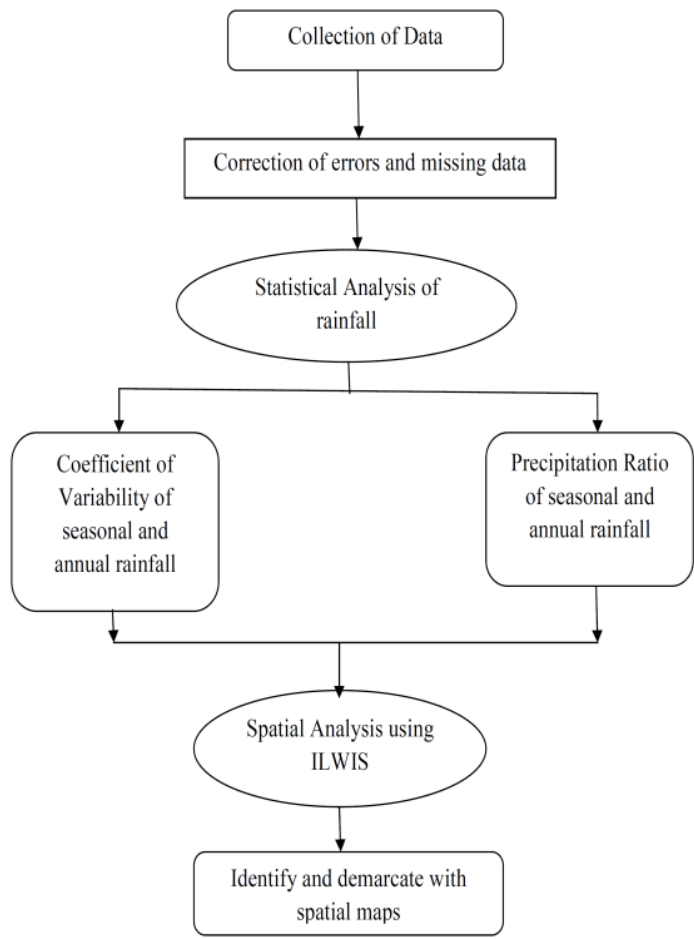

Figure 2 Flowchart showing methodology

This study has taken 21 rainfall stations and collected a data for 30 consecutive years' from the PWD during the period of 1986 - 2016. The annual and seasonal variations of rainfall such as summer, winter, North-East Monsoon and South-West Monsoon are analyzed as shown in table1. The Coefficient of Variability and Precipitation Ratio for all the stations, in the study area, have been found and the plot spatial distribution map has been drawn with the help of ILWIS. The ILWIS is a Geographical Information System Software. It was initially developed by researchers in Netherlands. The collected data and maps have been processed using ILWIS. It has been analyzed and interpolated by the method of Kriging in the ILWIS software as shown in figure 2 .

Table 1 Various Seasons of Rainfall

\begin{tabular}{|c|c|}
\hline SEASON & MONTH \\
\hline Winter & January - February \\
\hline Summer & March - May \\
\hline South-West Monsoon & June - September \\
\hline North-East Monsoon & October - December \\
\hline
\end{tabular}

\section{Variability of Rainfall}

The Rainfall Variability is the value to express the dependability of rainfall. The lower variability of percentage represents the higher dependability and vice versa. Rainfall
Variability is expressed as the ratio of the standard deviation to the mean rainfall.

$$
\begin{aligned}
& \mathrm{CV} \text { in } \% \quad= \\
& \frac{\text { Standard Deviation }}{\text { Mean Rainfall }} \times 100
\end{aligned}
$$

\section{Precipitation Ratio}

Precipitation Ratio resembles the abnormality of rainfall in the area. The higher value represents the higher abnormality, while the lower values show the lower abnormality. Precipitation Ratio is expressed as the ratio of difference between the maximum and minimum rainfall to the mean rainfall.

$\mathrm{PR}$ in $\%=\left[\left(\mathrm{P}_{\max }-\mathrm{P}_{\min }\right) / \mathrm{P}_{\text {mean }}\right] \times 100$

Where,

$\mathrm{P}_{\max }=\quad$ Maximum Rainfall in $\mathrm{mm}$

$\mathrm{P}_{\min }=$ Minimum Rainfall in $\mathrm{mm}$

$\mathrm{P}_{\text {mean }} \quad=\quad$ Mean Rainfall in $\mathrm{mm}$

\begin{tabular}{|c|c|c|c|c|c|}
\hline Station Name & 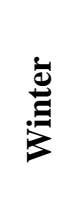 & $\begin{array}{l}\dot{\bar{\Xi}} \\
\dot{\Xi} \\
\bar{\Xi}\end{array}$ & 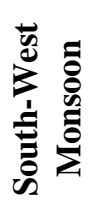 & 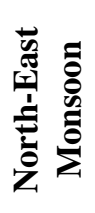 & 胥 \\
\hline Annamalainagar & 61.7 & 110.2 & 318.4 & 990.6 & 1480.9 \\
\hline Bhuvanagiri & 47.2 & 72.3 & 221.6 & 747.4 & 1088.5 \\
\hline Chidambaram & 63.3 & 105.5 & 294.1 & 949.7 & 1412.6 \\
\hline Cuddalore & 47.3 & 89.0 & 339.1 & 855.1 & 1330.4 \\
\hline Kattumailur & 12.3 & 85.4 & 296.5 & 554.1 & 948.3 \\
\hline Kattumannarkoil & 42.5 & 120.7 & 360.9 & 847.1 & 1371.2 \\
\hline Kilcheruvai & 18.9 & 125.0 & 484.4 & 678.9 & 1307.3 \\
\hline Kothuvacheri & 35.2 & 83.2 & 254.7 & 751.2 & 1124.3 \\
\hline Kuppanatham & 27.3 & 113.3 & 381.3 & 611.8 & 1133.8 \\
\hline Lekkur & 11.1 & 118.9 & 387.0 & 537.5 & 1054.6 \\
\hline Memathur & 22.7 & 96.9 & 345.5 & 698.9 & 1163.9 \\
\hline Palur & 49.1 & 103.5 & 284.4 & 796.9 & 1293.2 \\
\hline Panruti & 24.6 & 77.1 & 298.6 & 721.1 & 1121.5 \\
\hline Parangipettai & 54.0 & 80.5 & 284.4 & 951.2 & 1370.0 \\
\hline Pilandurai & 23.7 & 136.1 & 382.5 & 645.2 & 1187.5 \\
\hline Sethiathopeanicut & 46.3 & 100.2 & 359.3 & 807.7 & 1313.5 \\
\hline Srimushnam & 40.9 & 90.0 & 387.3 & 762.2 & 1280.4 \\
\hline Vanamadevi. & 37.0 & 65.4 & 283.8 & 655.9 & 1042.2 \\
\hline Tholudur & 14.1 & 142.8 & 439.5 & 652.9 & 1249.2 \\
\hline Veppur & 7.2 & 81.3 & 253.3 & 484.0 & 825.9 \\
\hline $\begin{array}{l}\text { Virudhachalamtal } \\
\text { uk office }\end{array}$ & 24.9 & 123.6 & 375.1 & 581.7 & 1105.3 \\
\hline Mean & 33.9 & 101.0 & 334.8 & 727.7 & 1200.2 \\
\hline
\end{tabular}

Table 2 Annual Mean and Seasonal Rainfall

Published By: 


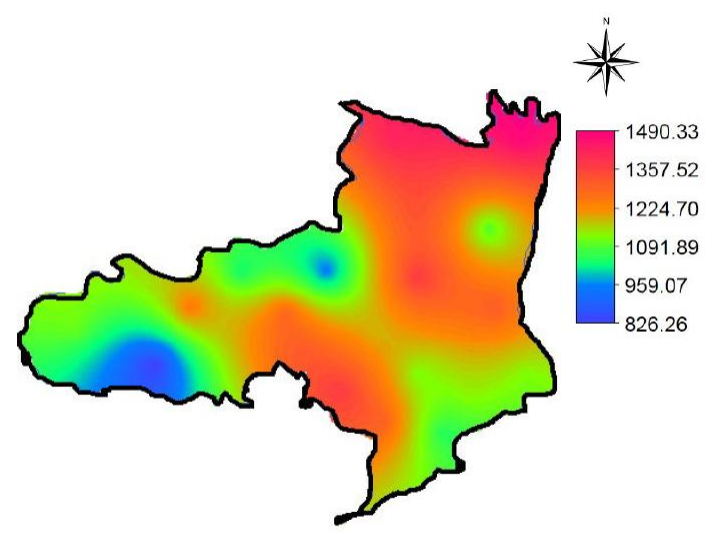

Figure 3 Spatial map of annual mean rainfall

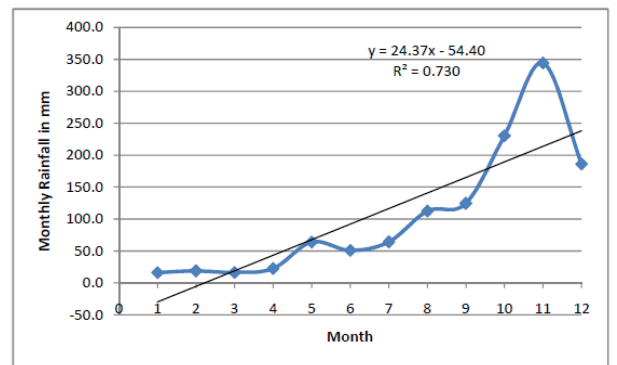

Figure 4 Monthly variation of Rainfall Pattern

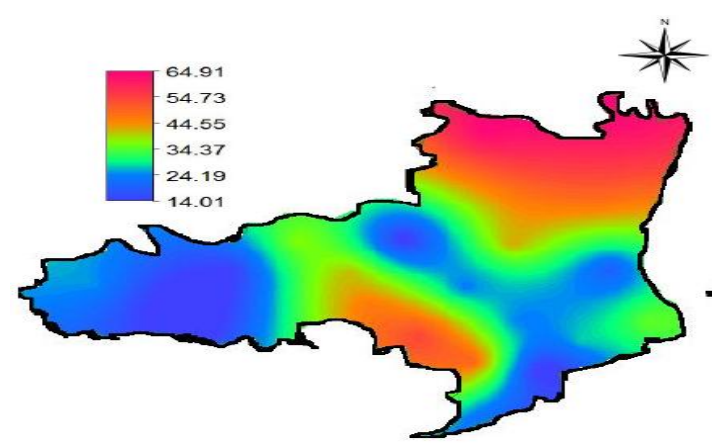

Figure 5 Spatial map of winter mean rainfall

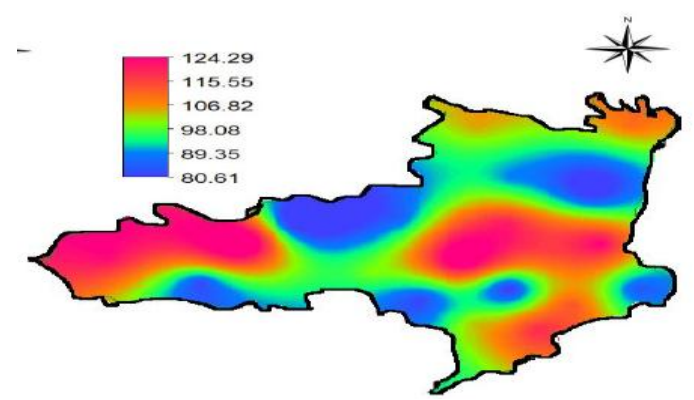

Figure 6 Spatial map of summer mean rainfall

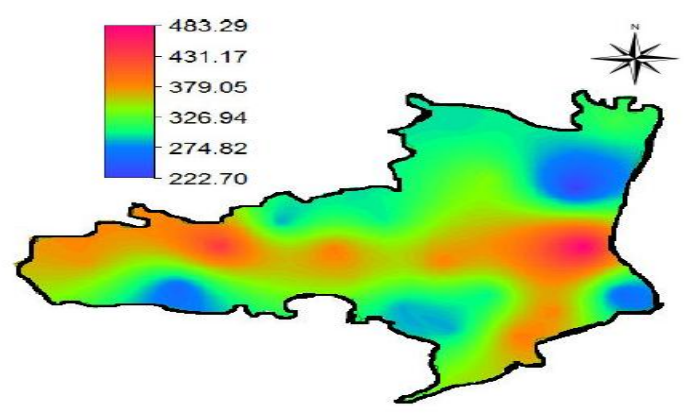

Figure 7 Spatial map of south-west monsoon mean rainfall

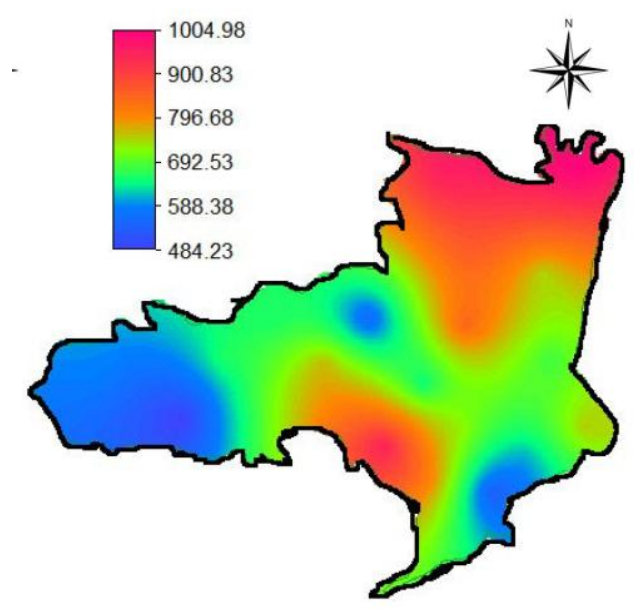

Figure 8 Spatial map of north-east monsoon mean rainfall

\section{RESULT AND DISCUSSION}

\section{Annual Mean Rainfall}

The average monthly rainfall, for the 21 stations under study for a span of 30 years, shows an increasing trend from January to December as shown in figure 4. It reaches the peak during North East Monsoon. The minimum mean is incurred as $825.9 \mathrm{~mm}$ at Veppur and Maximum as 1480.9 $\mathrm{mm}$ at Annamalai Nagar. The annual mean rainfall of all stations is $1200.2 \mathrm{~mm}$ as shown in figure 3 and table 2 . The results show the point that all the stations, except Kattumailur and Veppur, experience the high rainfall of more than $1000 \mathrm{~mm}$. The very high rainfall zones $(>1300$ $\mathrm{mm}$ ) include Annamalai Nagar, Chidambaram, Kattumannarkoil, Cuddalore, SethiayathopeAnicut, Kilcheruvai and Parangipettai. The high rainfall zones (1200 - $1299 \mathrm{~mm}$ ) include Srimushnam, Tholudur and Palur. The moderate rainfall zones (1100 - $1199 \mathrm{~mm})$ are Memathur, Kuppanatham, Kothavacheri, Panruti, Pilandurai and Virudhachalamtaluk office. The low rainfall zones (1000 $1099 \mathrm{~mm}$ ) are Bhuvanagiri, Lekkur and Vanamadevi. The very low rainfall zones $(<1000 \mathrm{~mm})$ are Kattumailur and Veppur.

For the last 30 years, the seasonal variations of North East Monsoon is observed with the maximum rainfall intensity $1600 \mathrm{~mm}(1993$ - 1994) in Srimushnam and the minimum rainfall intensity of $400 \mathrm{~mm}(1988-1989)$ in Bhuvanagiri. The seasonal variations of the South East Monsoon are observed and it is recorded with the maximum rainfall intensity of $800 \mathrm{~mm}(1998$ - 1999) at Kilcheruvai and the minimum rainfall intensity of less than $50 \mathrm{~mm}$ (2012 - 2013) at Tholudur. The seasonal variation of the summer is observed with the maximum rainfall intensity of $500 \mathrm{~mm}$ (2008 - 2009) at Annamalai Nagar and the minimum rainfall intensity of less than $30 \mathrm{~mm}(1990$ - 1991) at Kattumailur. The seasonal variation of the winter is observed with the maximum rainfall intensity of $400 \mathrm{~mm}(2002$ - 2003) at Annamalai Nagar and the minimum rainfall intensity of less than $30 \mathrm{~mm}(2010$ - 2011) at Kattumailur. 


\section{Mean Seasonal Rainfall}

\section{Winter Mean Rainfall}

During this period, very low rainfall is recorded which contributes to $2.75 \%$ of the total rainfall as shown in figure 5. The minimum and maximum rainfall is recorded at Veppur $(7.2 \mathrm{~mm})$ and Chidambaram $(68.3 \mathrm{~mm})$ respectively. The annual mean rainfall of this season is 33.9 $\mathrm{mm}$

\section{i. Summer Mean Rainfall}

It is a hot weather period. It contributes to $8.42 \%$ of the total mean rainfall having the mean of $101 \mathrm{~mm}$ as shown in figure 6 . The minimum and the maximum rainfall have incurred during this season with $65.4 \mathrm{~mm}$ at Vanamadevi and $142.8 \mathrm{~mm}$ at Tholudur.

\section{iiSouth West Monsoon Mean Rainfall}

During this season, the maximum and minimum rainfall occurred, at Kilcheruvai (484.4 $\mathrm{mm})$ and Bhuvanagiri $(221.6 \mathrm{~mm})$ is shown in figure 7 . The very high rainfall $(>400 \mathrm{~mm})$ is recorded at Kilcheruvai and Tholudur. The high rainfall (300 - $399 \mathrm{~mm}$ ) occurred at Annamalai Nagar, Cuddalore, Kattumannarkoil, Kuppanatham, Lekkur, Memathur, Pilandurai, Srimushnam, SethiyathopeAnivut and VirudhachalamTaluk Office. The moderate rainfall (200 - $299 \mathrm{~mm}$ ) occurred at Bhuvanagiri, Chidambaram, Kattumailur, Kothuvacheri, Palur, Panruti, Parangipettai, Vanamadevi and Veppur. This season contributes to $27.9 \%$ of the mean annual rainfall. The mean rainfall of this season is $224.8 \mathrm{~mm}$.

\section{iii. North East Monsoon Mean Rainfall}

The highest rainfall (>900 mm) occurred at Annamalai Nagar, Chidambaram and Parangipettai. The high rainfall (750 - $899 \mathrm{~mm}$ ) occurred at Cuddalore, Kattumannarkoil, Kothavacheri, Palur, SethiyathopeAnicut and Srimushnam as shown in figure 8 . The moderate rainfall $(650-749 \mathrm{~mm})$ occurred at Bhuvanagiri, Kilcheruvai, Panruti, Memathur, Vanamadevi and Tholudur. The low rainfall $(<650 \mathrm{~mm})$ occurred at Kattumailur, Lekkur, Pilandurai, Virudhachalamtaluk office, Veppur and Kuppanatham. The presence of Bay of Bengal on the eastern side of the study area influences the weather conditions and brings high rainfall to the coastal regions and it is found decreasing as it moves towards the West. The mean annual rainfall of this period is $727.7 \mathrm{~mm}$ and it contributes to $60.6 \%$ of total the mean annual rainfall.

Variability of Annual and Seasonal Rainfall Table 3 Annual and Seasonal Rainfall Variability in \%

\begin{tabular}{|c|c|c|c|c|c|}
\hline$\stackrel{\Xi}{\stackrel{\Xi}{\Xi}}$ & 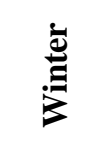 & $\stackrel{\grave{\Xi}}{\grave{\Xi}}$ & 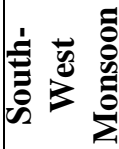 & 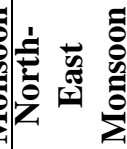 & 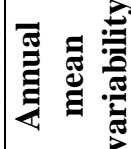 \\
\hline Annamalainagar & 144.32 & 110.13 & 35.72 & 33.07 & 27.32 \\
\hline Bhuvanagiri & 185.66 & 108.67 & 53.33 & 51.61 & 46.97 \\
\hline Chidambaram & 166.55 & 108.16 & 38.26 & 37.25 & 29.65 \\
\hline Cuddalore & 148.78 & 89.78 & 35.08 & 42.54 & 31.49 \\
\hline Kattumailur & 189.43 & 84.61 & 49.66 & 47.19 & 33.98 \\
\hline
\end{tabular}

\begin{tabular}{|c|c|c|c|c|c|}
\hline Kattumannarkoil & 201.93 & 104.73 & 50.75 & 46.38 & 37.94 \\
\hline Kilcheruvai & 204.70 & 93.56 & 38.95 & 51.47 & 38.04 \\
\hline Kothuvacheri & 190.49 & 106.20 & 40.79 & 45.46 & 35.68 \\
\hline Kuppanatham & 164.47 & 93.92 & 35.13 & 49.08 & 34.49 \\
\hline Lekkur & 149.69 & 70.09 & 36.83 & 45.59 & 32.43 \\
\hline Memathur & 223.71 & 76.11 & 36.03 & 43.65 & 30.51 \\
\hline Palur & 186.41 & 99.44 & 46.38 & 45.70 & 33.59 \\
\hline Panruti & 162.43 & 139.19 & 58.36 & 58.42 & 46.93 \\
\hline Parangipettai & 145.19 & 123.45 & 43.67 & 40.90 & 29.57 \\
\hline Pilandurai & 159.25 & 55.20 & 35.45 & 42.43 & 30.49 \\
\hline $\begin{array}{c}\text { Sethiyathopeani } \\
\text { cut }\end{array}$ & 169.59 & 87.41 & 28.48 & 43.11 & 30.79 \\
\hline Srimushnam & 217.57 & 101.14 & 50.17 & 49.70 & 40.92 \\
\hline Vanamadevi. & 203.96 & 123.29 & 59.50 & 58.52 & 52.28 \\
\hline Tholudur & 185.67 & 71.18 & 46.45 & 53.02 & 38.24 \\
\hline Veppur & 211.53 & 114.36 & 72.92 & 63.29 & 55.23 \\
\hline $\begin{array}{c}\text { Virudhachalamt } \\
\text { aluk office }\end{array}$ & 170.67 & 80.31 & 33.34 & 49.80 & 34.72 \\
\hline
\end{tabular}

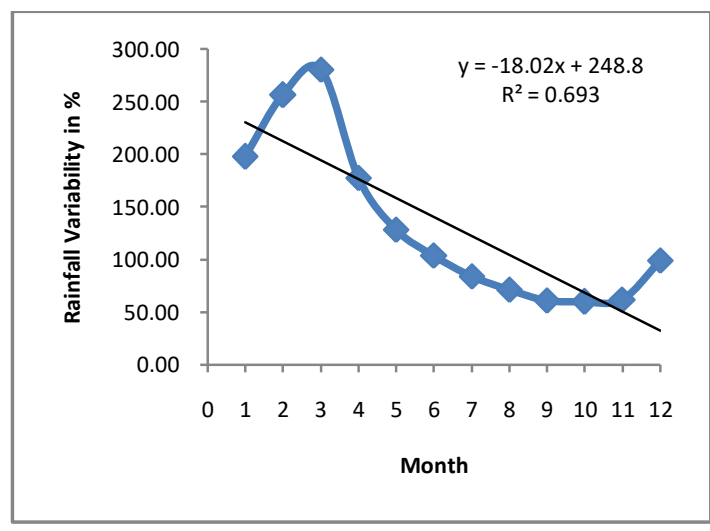

Figure 9 Rainfall Variability on month wise

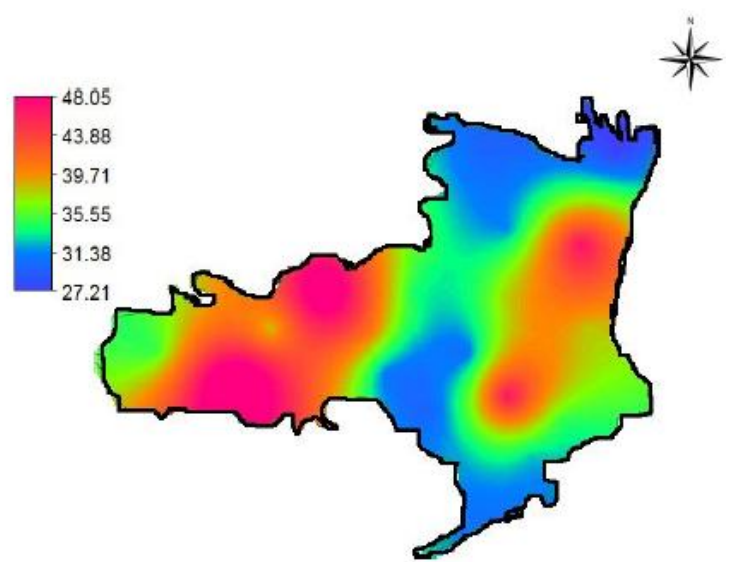

Figure 10 Spatial map of annual mean rainfall Variability

The monthly Rainfall Variability follows a decreasing trend from January to December as shown in figure 9. It reaches the peak during March and takes a decreasing trend

Published By: 
up to the year end as shown in table 3. The Rainfall Variability varies between $27.31 \%$ and $55.22 \%$ at Annamalai Nagar and Veppur respectively. The higher dependence is recorded at the South and South Eastern part of the study area as shown in figure 10. The maximum Rainfall Variability is is found occuring during winter season followed by the Summer and North East Monsoon and the minimum is recorded during South West Monsoon. The result indicates the fact that the maximum rainfall is the deciding factor. The dependability is found more during the Monsoon period. The mean Rainfall Variability is $36.72 \%$. For all seasons, it stretches between $223.71 \%$ and $33.07 \%$.

\section{Precipitation Ratio}

Table 4 Station wise precipitation ratio in $\%$

\begin{tabular}{|c|c|c|c|c|c|}
\hline 咅 & 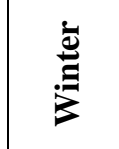 & $\stackrel{\bar{\Xi}}{\grave{\Xi}}$ & 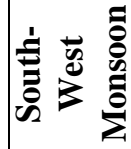 & 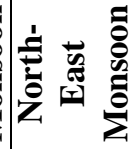 & 蒠 \\
\hline Annamalainagar & 667.23 & 546.98 & 156.18 & 154.11 & 145.72 \\
\hline Bhuvanagiri & 750.31 & 464.73 & 196.29 & 169.79 & 157.93 \\
\hline Chidambaram & 655.31 & 476.90 & 174.19 & 162.01 & 148.03 \\
\hline Cuddalore & 618.31 & 387.91 & 154.25 & 190.39 & 132.72 \\
\hline Kattumailur & 852.09 & 367.81 & 189.96 & 207.90 & 169.15 \\
\hline Kattumannarkoil & 1057.11 & 399.20 & 214.99 & 184.17 & 152.42 \\
\hline Kilcheruvai & 891.90 & 358.29 & 163.08 & 211.95 & 159.15 \\
\hline Kothuvacheri & 886.97 & 371.24 & 147.61 & 200.08 & 159.20 \\
\hline Kuppanatham & 608.63 & 449.88 & 147.84 & 189.59 & 147.32 \\
\hline Lekkur & 583.04 & 350.68 & 154.40 & 207.14 & 144.94 \\
\hline Memathur & 1095.02 & 304.38 & 157.76 & 212.63 & 154.27 \\
\hline Palur & 646.17 & 372.60 & 176.87 & 195.38 & 139.58 \\
\hline Panruti & 564.81 & 588.97 & 213.56 & 262.61 & 194.43 \\
\hline Parangipettai & 562.24 & 514.12 & 168.80 & 172.58 & 157.41 \\
\hline Pilandurai & 669.70 & 274.12 & 153.73 & 178.55 & 133.31 \\
\hline $\begin{array}{c}\text { Sethiyathopeani } \\
\text { cut }\end{array}$ & 673.96 & 389.78 & 101.94 & 166.15 & 131.67 \\
\hline Srimushnam & 812.06 & 367.91 & 197.80 & 220.41 & 182.13 \\
\hline Vanamadevi. & 803.45 & 517.16 & 275.49 & 202.07 & 206.55 \\
\hline Tholudur & 718.45 & 259.12 & 198.92 & 249.95 & 184.35 \\
\hline Veppur & 768.51 & 432.71 & 233.16 & 213.41 & 202.41 \\
\hline $\begin{array}{c}\text { Virudhachalamt } \\
\text { aluk office }\end{array}$ & 553.98 & 403.19 & 138.70 & 203.78 & 142.74 \\
\hline mean & 735.20 & 409.41 & 176.93 & 197.84 & 159.31 \\
\hline
\end{tabular}

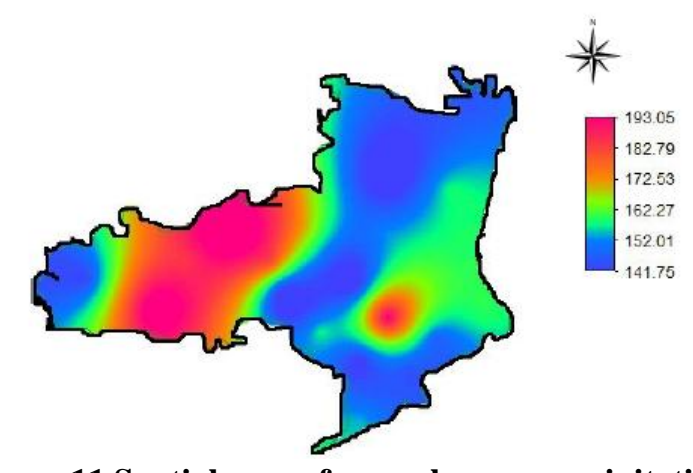

Figure 11 Spatial map of annual mean precipitation ratio

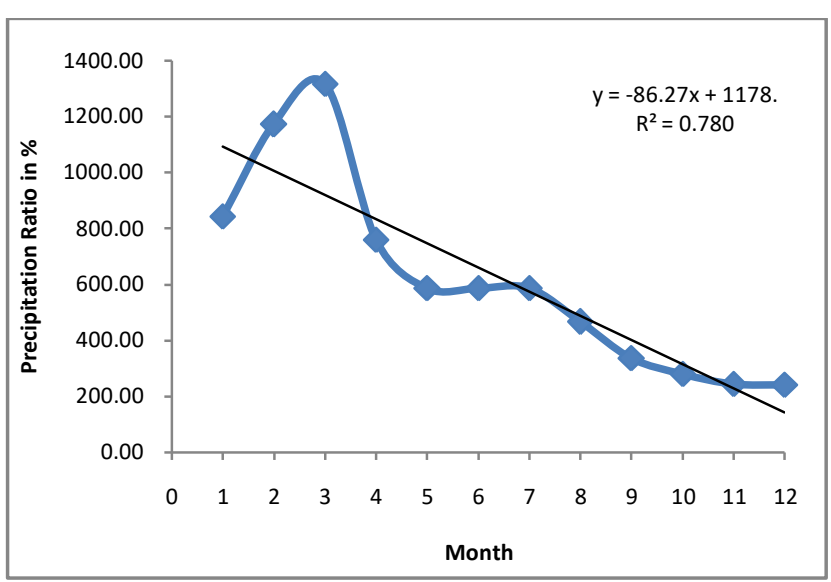

Figure 12 Month wise Precipitation Ratio

It extends between $1095.02 \mathrm{~mm}$ during winter at Memathur and 101.94 during South-West Monsoon at SethiyathopeAnicut. The maximum abnormality is obtained during the Winter followed by Summer and North East Monsoon periods as shown in figure 11. The minimum is obtained during South West Monsoon and the Precipitation Ratio follows a decreasing trend. The peak is achieved during March as shown in figure 12. The least value or Abnormality is obtained during November month. The maximum and minimum value for all the 21 stations is 206.55 at Vanamadevi and 131.67 at SethiyathopeAnicut. The mean annual Precipitation Ratio is $159.31 \%$ as shown in table 4.

\section{CONCLUSION}

The present study deals with the distribution of rainfall, Coefficient of Variability and Precipitation Ratio at 21 stations chosen for observation in Cuddalore district. It shows the seasonal and annual rainfall pattern. The temporal and spatial distribution of rainfall is vital for planning of water resource projects and other agricultural activities. In general, the study area comprises of 3 zones with respect to the altitude. The region having low altitude receives high rainfall. The middle zone obtains moderate rainfall. The high altitude zone experiences low rainfall.

The results of the analysis depict the inverse relationship between the Rainfall and Rainfall Variability. Low 
Variability indicates the mean rainfall at the given location as reliable, whereas the high variability denotes the wide fluctuations.

Winter Season: During this season, very small amount of rainfall is observed in the western region of the study area. It also shows the higher value of variability and precipitation ratio which represents less dependability and higher abnormality of rainfall.

Summer Season: During this period, no huge difference in rainfall for all the 21 stations is observed. In other words, the rainfall is almost even.

South-West Monsoon Season: This season brings more rainfall on the North- Western part of the study area. The places high altitude experience more rainfall in this season. The middle and Eastern parts get moderate to less rainfall.

North-East Monsoon Season: It is contrast to the SouthWest Monsoon. It brings more rainfall to all the places of the study area than other seasons, especially, the places low altitude and the areas nearer to sea, experience very high rainfall.

Coefficient of Variability: The moderate dependability of rainfall is simply even among the middle to the Eastern part where the altitude is medium, whereas the high dependability is observed on the South-East region where the altitude is low. The low dependability is experienced in a very few places where the altitude is high.

Precipitation Ratio: Lesser Abnormality is found in the central part of the study region, whereas the Northern and Southern show the maximum abnormality.

\section{REFERENCES}

1. Alak Gadagil,1986, Annual and weekly analysis of rainfall and temperature for Pune: a multiple time series approach. Inst. Indian Geographers. Vol.8 No.1.1986.

2. Alexander.G.,Keshavamoorthy. U Fluctuations of monsoon activity, Indian J. Meteor. Geophs, 29, 76-87, 1978.

3. Annamali . H and J Slingo, Active/ Break cycles:diagnosis of the intraseasonal variability of the Asian summer, ClimDn 1885 102, 2001.

4. Blanford, H.F., Rainfall of india. MemInd Met. Dept., $2217-$ $448,1886$.

5. Fowler. H., S. Blenkinsop, C.Tebaldi., 2001: Linking Climate change modeling to impacts studies: Recent anvances in downscaling techniques for hydrological modellingJ.Climatol., 27 547-1578.

6. Gadgil., S and P.V.Joseph On breaks of Indian Summer Monsoon, Proc., Indian Acad. Sci. 112,529 - 558, 2003.

7. Gowsami, B, V.KrishnamooethiH.Annamalai., Abroad scale circulation index for the interannual variability of the Indian summer monsoon QJRMS 125:611-633, 1999.

8. Kohenen, T., The self organizing Map. Procc IEEE14641480,1990

9. Krishnamuethi,T and H.N Blamlme Oscillation of monsoon system Part I Observational Aspects Sci.,33 1937-1954,1976.

10. Malurkar,S.L Notes on analysis of weather of India and neighborhood, Memoirs of I.Met.DXXVH Part IV, 139215,1950 .

11. Rgavan,K., Break monsoon over India, Mon Wea. Rev., 101.33-43.,1973.

12. Sandeep. P R. Jegankumar., Assesment of spatial variability of rainfall pattern IJRCT 2320-2882, 2018. 